\title{
O poder judiciário como legislador positivo atípico
}

\author{
The JUDICIAL POWER AS POSITIVE LEGISLATOR \\ ATYPICAL
}

\author{
José Armando Ponte Dias Junior * \\ Dayane Karla Barros de Farias Duarte **
}

* José Armando Ponte Dias Junior, Mestre em Direito Constitucional pela Universidade Federal do Ceará, especialista em Processo Penal pela Universidade de Fortaleza e graduado em Direito pela Universidade Federal do Ceará. Professor Efetivo da Universidade do Estado do Rio Grande do Norte (UERN), onde tem ministrado disciplinas nas áreas do direito penal, direito processual penal, direito constitucional e direito eleitoral. juiz de direito da Comarca de Natal/RN. E-mail: armandojunior@uern.br

** Dayane Karla Barros De Farias Duarte, Graduanda em Direito pela UERN - Campus Natal, com ênfase em Direito Digital, atuando principalmente nos seguintes temas: redes digitais, danos e responsabilidade civil. Trabalha como Técnica em Administração na UFRN. E-mail: dayanekarlabf@gmail.com

Resumo: O presente artigo versa sobre o ativismo jurídico e suas consequências. Destaca-se, de um lado, a rigidez de percepções, a lentidão judicial, a ofensa aos direitos humanos e ao princípio da separação de poderes; de outro, a certeza do direito, a aplicação de princípios com proporcionalidade, a celeridade processual, a igualdade, a justiça, a garantia dos princípios constitucionais, a flexibilização da antiga e estagnada ideia de divisão dos poderes, o aperfeiçoamento do trabalho de julgamento do magistrado, além das cobranças urgentes a serem feitas ao legislador. Debate-se a progressão jurisdicional brasileira a partir do precedente judicial, das súmulas, das súmulas vinculantes e das peculiaridades do direito do trabalho e eleitoral. Com fundamentação baseada em analogias, teorias e novas concepções coloca sob refutação o problema de o Poder Judiciário ser legítimo ou não para legislar atipicamente.

Palavras-chave: Juiz Legislador. Ativismo Judicial. Súmula. Corte Constitucional.

Abstract: This article focuses on legal activism and its consequences. Stands on one side, the rigidity of perceptions, the slowness in the judicial process, the offense to human rights and the principle of separation of powers; on the other, the certainty of law, the application of principles with proportionality, the speed of the procedure, the equality, justice, the guaranteed constitutional principles, the flexibilization of the old and stagnant idea of separation of powers, the improvement of the work of the trial judge, in addition to pressing charges to be made to the legislature. Debates the progression of Brazilian court from the judicial precedent, the summaries, the binding summaries, the peculiarities of labor and election law. With reasoning based on analogies, theories and new conceptions puts the problem under refutation of the Judiciary Power be legitimate or not to legislate atypically.

Keywords: Judge as Legislator. Legal Activism. Summary. Constitutional Court. 


\section{INTRODUÇÃO}

Não há consenso acerca da prática da atividade legislativa pelo Poder Judiciário. Dessa forma, a princípio, carece de se construir uma noção evolutiva da atividade jurídica no Brasil, notando-se que o juiz deixou de ser tão somente a "boca da lei" e passou a usar, de forma limitada, a sua capacidade "criadora", dando azo ao que se vem denominando de ativismo judicial, contexto esse no qual estão inseridos os precedentes judiciais, as súmulas e as súmulas vinculantes, temas abordados no presente estudo.

São, pois, essas ideias fundamentais que alicerçarão este artigo, enfocando nos argumentos de que os juízes legislam sob o contexto constitucional que consolida a posição de destaque do Poder Judiciário ante a crescente necessidade de imprimir efetividade aos direitos fundamentais estabelecidos na Carta Política.

\section{METODOLOGIA}

No que diz respeito aos setores de conhecimento, este estudo classificase como interdisciplinar, envolvendo principalmente, as áreas de Direito Constitucional, Eleitoral, Trabalhista, além da História do Direito. Trata-se de pesquisa explicativa, em virtude de um aprofundamento desenvolvido partindo de um assunto específico e importante, porém pouco discutido; qualitativa; e construída a partir de referências bibliográficas. A partir da definição e da delimitação do tema do artigo, optou-se pela Dialética e Fenomenologia como quadro referencial.

\section{UMA VISÃO GERAL DAATIVIDADE JURÍDICA}

Conquanto antiga a problemática, ainda hoje se discute a respeito das funções desempenhadas pelos juízes de Direito: estariam estes com poder além do que lhes cabe? Estariam inventando o Direito? Muitos argumentos plausíveis são apresentados por ambos os lados, instaurando assim dúvidas em todos os estudantes e admiradores da ciência jurídica. Sendo assim, como profissionais cientistas, deve-se realizar um estudo aprofundado levando em conta opiniões divergentes dos maiores juristas e filósofos, e então defender uma opinião.

Observou-se no século XX a dilatação do Poder Executivo, e semelhantemente, no século XXI, o Poder Judiciário apresenta-se em constante expansão. Por conseguinte, as discussões acerca de suas funções aumentam 
de forma gradativa, surgindo uma indagação: afinal, porque o judiciário ganhou tal destaque?

Como bem afirmou Cappelletti (1999), esse crescimento deve-se à ampliação do próprio Estado, e ao se analisar o histórico mundial, observa-se que cada esfera do poder teve seu momento de crescimento destacado: no século XIX foi o Poder Legislativo; no século XX, o Poder Executivo. Este fato também pode ser visualizado no Brasil e, acerca de tal desenvolvimento - em momentos diferentes - das funções do poder, destaca Bemfica (1995, p. 38) que a Constituição Federal de 1988 alforriou o Poder Judiciário do Poder Executivo, o seu Senhor. E hoje, aquele está autônomo administrativa e financeiramente e assim, preparado para garantir um Estado Constitucional de Direito.

Daí percebe-se a importância da Carta Magna não só para com as pessoas de direito, mas também para um judiciário ativo, estruturado e forte, somando em um Estado Garantista. Tanto é que um dos motivos de toda esta polêmica tem como um dos seus fundamentos o princípio da inafastabilidade da jurisdição assegurada no artigo $5^{\circ}$, inciso XXXV da Constituição Federal que, basicamente, garante o ingresso em juízo para assegurar a ameaça a direito, ampliando assim, o acesso ao Judiciário antes mesmo da concretização da lesão.

\subsection{O início da ruptura do formalismo}

Há algumas gerações os juízes eram tidos apenas para afirmar a lei. Mas porque nos dias atuais a possibilidade de criação já é naturalmente praticada pelo Poder Judiciário? Um dos motivos é a visão geral: a não recepção do formalismo. Ou seja, observava-se e também se cultivava um jurisdicionalismo mecânico e lógico-dedutivo com os pensamentos positivistas, uma mera declaração de direitos proferidos pelo juiz desconsiderando seus pensamentos repletos de valores individuais.

Tais lutas proporcionaram concepções distintas das pioneiras. Agora se percebeu que o juiz tem responsabilidades grandes e complexas e viu-se ainda que o direito não é matéria exata e clara, mas que possui espaços em branco a serem cuidadosamente preenchidos. O que se analisa é se tamanho aumento de responsabilidades do juiz foi ou está sendo construtivo ou não. Quer-se saber ainda se estaria havendo uma transformação do juiz em um legislador e se tal situação ocasionaria uma quebra da ideia inicial de separação do poder, o que poderia levar a um estado com funções hipertrofiadas. 
A magistratura, mais especificamente a dos tribunais superiores, transmitia uma imagem tradicionalista, fechada a novos pensamentos. Mas porque os juízes abandonaram o formalismo? Um acontecimento que corroborou foram as mudanças ocorridas no Estado em relação ao seu papel para com a sociedade em geral, preocupação esta que ocasionou a institucionalização do "Estado de Bem-Estar Social", acompanhada de uma forte atividade legislativa. A partir de então começa a se atentar não apenas para as decisões individuais, mas preocupa-se também em fazer o entrelaçamento com as finalidades sociais.

Com as mudanças advindas da nova legislação do Estado de bemestar social, concedeu-se ao Poder Executivo alguns poderes de decisão, de regulamentação e de delegação legislativa para determinados casos e, semelhantemente, o Poder Legislativo também apresentou alterações: agora, a legislação contempla também os princípios e as finalidades, observando sempre os direitos sociais - e não apenas os individuais, como outrora -, além de as leis serem programáticas e ativas, contando com a ação estatal.

Assim sendo, ao passo que a legislação começa a envolver cada vez mais conceitos abstratos e abertos, abrem-se também espaços para maior grau de interpretação do juiz, havendo uma maior discricionariedade nas suas decisões.

Devido ao crescimento do Estado, os Parlamentos atribuíram a si próprios diversas funções, mas como a ambição foi maior do que a disponibilidade de deixar seus interesses políticos e partidários - geralmente individuais - de lado e responder rapidamente à sociedade, houve um fenômeno de obstrução. E, para não ocorrer paralisação, teve-se que abdicar e transferir grande parte destas atividades a outrem, no caso, ao executivo e os seus órgãos derivados, os quais foram confiados a tarefas de cunho normativo e administrativo. No entanto, tornou-se cada vez mais presente $o$ sentimento de insatisfação, desesperança e desconfiança não só para com o Legislativo, mas também ao Executivo.

Assim, o judiciário recebeu novas responsabilidades, como a justiça constitucional e sua forma de controle judiciário da legitimidade constitucional das leis e da atividade do executivo e seus derivados. A consequência foi um "gigante poder", que leva a um perigoso desequilíbrio no sistema de tripartição das funções do poder, fazendo as sociedades reagirem, instituindo organismos "quase jurídicos" com a função de controlar os "poderes políticos", os quais devem proteger a sociedade não somente de abusos, 
mas também de autoritarismo, demora, gravosidade, inacessibilidade, irresponsabilidade e inquisitoriedade.

\subsection{A nova concepção da separação das funções do poder}

Um ponto bastante importante e, talvez, até pouco debatido: a legitimidade dos poderes. Afinal, de certa forma, os legisladores politicamente eleitos e os administradores politicamente responsáveis, atuam, aparentemente, com um maior grau de legitimação se comparado ao ativismo judiciário presente hodiernamente.

É interessante observar certas divergências entre os dois sistemas Common Law e o Civil Law - em um mesmo momento de grande desenvolvimento, já que no primeiro proibiram-se os tribunais ordinários de adentrar nos novos campos dos conflitos sociais; todavia, no segundo, apareceram novos órgãos especiais, como os "Conselhos de Estado", mais tarde "Cortes Constitucionais". No entanto, as diferenças são progressivamente menores entre as famílias, as quais parecem convergir para um único sistema globalizado composto pela união de experiências conquistadas nos sistemas jurídicos originais.

Ao se aprofundar um pouco mais acerca da "divisão de poderes", notase que tal segmentação fora feita, "a priori”, de forma intensamente rígida, ao invés de se utilizar do controle de freios e contrapesos, o qual parte da ideia de equilíbrio recíproco. Dessa forma, ao invés de cada função do poder ser forte, apenas uma, momentaneamente, tornava-se forte, enquanto as demais estavam defasadas. Assim, é preciso eliminar a concentração de poder, fazendo uma melhor repartição entre tais funções.

Tanto é que em pesquisa feita pela Fundação Getúlio Vargas(CUNHA et al., 2012), o Poder Judiciário apareceu com um percentual de 42\% (quarenta de dois por cento) de confiança da população. Comparado a outras instituições, o Judiciário ficou em $6^{\circ}$ (sexto) lugar, perdendo para as Forças Armadas, a Igreja Católica, o Ministério Público, as Grandes Empresas e a Imprensa Escrita; e ganhou para o Governo Federal, a Polícia, as Emissoras de Televisão, os vizinhos, o Congresso Nacional e os Partidos Políticos.

A partir destes dados pode-se inferir dois pontos: o primeiro, é que se constata o argumento anteriormente discutido de que as funções do poder aqui no Brasil assumem, de forma intercalada, o destaque e o crescimento, já que o Judiciário apresentou quase o dobro de confiança social do que o Congresso Nacional, por exemplo; o segundo, é que apesar do destaque do judiciário frente 
às outras funções, mesmo assim tal resultado é insatisfatório, já que nem metade da população brasileira confia no judiciário, sinal que é preciso medidas urgentes de mudanças estruturais no Estado e na própria sociedade como um todo, partindo-se de um massivo investimento na educação e na tecnologia.

\subsection{Surgimento de novos direitos}

A Revolução Industrial ocasionou o surgimento do Estado de Bem Estar Social e o crescimento dos ramos legislativo e administrativo, os quais corroboraram juntamente com a Revolução para um processo presente até os dias de hoje: a massificação, cuja principal característica é o rápido e simples envolvimento de inúmeras pessoas com apenas uma ação, como um simples clique de mouse. Dessa forma, as pessoas desejam cada vez mais que seus bens sejam realmente protegidos tanto no âmbito político quanto no jurídico.

A partir de tal situação, a população espera e exige a reparação de seus direitos violados, sejam eles individuais, coletivos ou de classe. Os juízes poderiam simplesmente negar tais pedidos, "fechando os olhos" para a realidade da carência por soluções sociais. Todavia, o judiciário se mostrou apto às requisições de um mundo completamente diferente. Caso contrário, ou surgiria aos poucos um órgão "quase judiciário" ou os próprios juízes cresceriam de forma tal que eles mesmos seriam os guardiões dos novos direitos de terceira, quarta e quinta dimensão.

Não há de se olvidar que esses direitos que estão surgindo são, em regra, programáticos, vagos e fluidos, sendo forçoso - e até preciso - o elevado grau de criatividade e ativismo do juiz para poder não tão somente interpretálos, mas aplicar a hermenêutica e a equidade.

Catálogos de Direitos Humanos, como o Bill of Rights, foram elementos centrais da maioria das constituições do século $\mathrm{XX}$ - em especial aquelas dadas em reação aos regimes ditatoriais - sendo ainda mais necessária a proteção jurisdicional dos direitos fundamentais, contribuindo sensivelmente para a dilatação do fenômeno da justiça constitucional.

A partir do momento em que as declarações dos direitos fundamentais deixaram de fazer parte apenas do plano filosófico e passaram também ao de atuação dos tribunais, o fenômeno do "terceiro gigante" teve um grande desenvolvimento, aumentando o alcance do direito judiciário e, concomitantemente, a criatividade dos juízes. 
É conveniente observar ainda que tais "novos direitos" exigem também uma intensa intervenção estatal para que se atinjam os objetivos de concretização e efetivação. Além de que os catálogos de direitos fundamentais são formulados sobre valores como liberdades, dignidade, igualdade, democracia, justiça, dentre outros. E tal peculiar característica não deve ser vista de forma negativa, entretanto se vislumbra que é justamente por tal textura aberta e de baixa densidade que permite a mutação constitucional e sua volátil e flexível adaptação, mudanças e transformações em consonância com as vontades e necessidades da sociedade moderna, pluralista e tecnológica. Assim, chega-se à conclusão de que a exatidão levaria a constituição a uma súbita morte.

\subsection{O equívoco conceito do contramajoritário}

A maior barreira à criatividade judiciária é no que diz respeito ao caráter não majoritário e, sendo assim, alegado por alguns, antidemocrático. Tal entrave é ainda mais observado quando a criatividade se exerce no âmbito do controle judiciário das leis.

No que concerne ao paradigma, já comentado anteriormente, da democracia representativa, Cappelletti (1999) entende que não é porque os líderes legislativos e executivos são a "vontade do povo", não implica em uma perfeita representação. Entretanto, há de se convir que, na prática, é mais dificultoso de os legisladores serem a voz do povo, em decorrência da complexa estrutura política atuante formada por vários grupos poderosos, com interesses divergentes que buscam incessantemente o centro do poder. Ao contrário do judiciário que, em regra, não possui tais barreiras e também se mostra responsável perante a população, preocupando-se em tornar públicas suas decisões e fundamentá-las em argumentos convincentes. Assim, semelhantemente, os tribunais sofrem certo controle por parte da população.

Na realidade, o juiz submerge na área de criatividade ao lidar com o direito e com os valores, sendo que o maior problema está essencialmente concatenado com o grau de criatividade aplicado, pois há limites restritivos. Para Cappelletti (1999), os juízes necessitam participar da criação do direito, desde que, dentro do limite, não retire completamente a competência de o legislador anular (ab-rogar) ou alterar o direito jurisdicional.

Contudo atualmente esta concepção deve ser refeita, uma vez que realmente deve haver limites e a competência do legislador deve ser assegurada a este consoante as circunstâncias apresentadas, utilizando-se da 
proporcionalidade em sentido estrito, da ponderação e da adequação, como bem teorizou Robert Alexy (2011). No entanto, o direito é alterado sim, pelos juízes, como se perceberá mais à frente neste artigo.

Os que concordam com as ideias expostas por Cappelletti (1999) asseguram que tais poderes se complementam no seguinte ponto: o legislativo tem contato com problemas gerais e abstratos; por outro lado, o judiciário está diariamente imerso por casos concretos e atuais, o que leva a este, por sua própria essência, a ser a "voz da razão", sendo responsáveis por redescobrir, idealizar, articular e desenvolver princípios práticos e duradouros. Afinal, o direito nunca será completo e inteiramente acabado, precisando sempre de ajustes.

No entanto, os adeptos desta teoria não aparentam aceitar o pensamento de que não há um limite concreto entre as funções do poder, uma vez que se entende hoje que a separação é flexível e porosa. Além do mais, é importante que o legislativo ao criar as leis se baseie na experiência do judiciário, nas orientações ditadas por este, e não se confie em "achismos" e probabilidades. Pode-se elencar ainda a questão da acessibilidade aos tribunais e às câmaras legislativas: aqueles exigem tão somente a vontade da parte; já estas parecem estar "cobertas de mistérios". E, também, aparentemente, não se atenta para a força normativa trazida pelas Súmulas Vinculantes, as quais serão discutidas (ponto 6.2).

Portanto, em suma, democracia é muito mais do que a ideia da majoritariedade: é participação, tolerância e liberdade. E para isso, precisase de um judiciário que garanta os direitos da sociedade, de forma ativa, dinâmica e criativa, como a sociedade também o é. Afinal, nas palavras de Cícero (apud BEMFICA, 1995, p. 25): "Nada pode ser honesto quando falta a justiça".

\subsection{O Judiciário como responsável pela evolução do direito}

Um notório ponto negativo observado nos tribunais é o grande volume de casos a serem julgado, o que afeta, indubitavelmente, a qualidade das decisões, uma vez que não há tempo suficiente para "pensar o direito". Em modo especial, no caso das Cortes Supremas, pode até ocorrer, infelizmente, de estas deixarem de exercer sua primordial função: esclarecer, guiar e atualizar o direito.

Dados inéditos coletados pelo Projeto Meritíssimos, da Transparência Brasil (2012), que tem como intuito divulgar o desempenho dos ministros 
do STF através da quantidade de processos abertos, congestionados e a expectativa de resolução, vem a corroborar com a ideia da alta demanda de casos a serem julgados pela Corte, o ministro Dias Toffolli é o que tem mais congestionamento são 10.111 (dez mil cento e onze) processos à espera de resolução; o ministro que está menos congestionado é Cezar Peluso com 1.688 (mil seiscentos e oitenta e oito) processos abertos; já o ministro presidente da Corte Suprema, Carlos Britto, quase não tem congestionamento por seus processos terem sido redistribuídos.

No que diz respeito às expectativas de resolução, estas variam de 38 a 83 semanas, a depender do ritmo de cada ministro e da classe processual que será analisada. E, finalmente, o número total de congestionamentos de processos a cada ano, desde 1997 até 2012, o que se pode contemplar um declínio de 2006 a 2011, chegando até 02 de julho de 2012 (última data de atualização da pesquisa) com quase 68 mil processos acumulados.

Além do mais, segundo várias análises - teóricas e práticas - feitas por Cappelletti (1999), tal processo de ativismo ocorre quase da mesma forma em ambos os sistemas de maior destaque mundial: o Common Law e o Civil Law. E, hodiernamente, tal enlace vem ficando mais nítido e mais forte através do fenômeno da globalização e da revolução tecnológica, unindo as principais famílias do direito mundial, um aspecto aparentemente positivo.

Apesar de a responsabilidade pela formação e pela evolução do direito terem sido depositadas no Poder Judiciário, deve-se deixar claro que justamente com o intuito de atalhar a pura subjetividade, devem ser demonstrados os conflitos existentes acerca das plausíveis soluções, além de serem acessíveis as reais causas de qualquer escolha judiciária, deixando, em regra, à disposição para interferências reparadoras do legislador.

Como disse Bemfica (1995, p.6):

Cada poder do Estado tem suas funções específicas. Via de regra, o Executivo exerce a função executiva, administrando e gerindo a coisa pública. $\mathrm{O}$ legislativo cria o direito, elaborando as leis, que disciplinam o modus vivendi dos indivíduos no meio social. O Judicial dirime os conflitos, fazendo atuar a lei para dar a cada um o que é seu. (grifo nosso)

Estaria, pois, o Judiciário dirimindo o modo de viver do brasileiro? Ou seja, através das sentenças, decisões, julgamentos ou súmulas, se estão ordenando 
o que deve ser feito? Afinal, é permitido a uma mulher, hoje, "abortar" de um feto anencéfalo ${ }^{1}$ ? Como pode o judiciário dar a cada um o que é seu de direito, se o legislador ainda aparenta estar adormecido - ou preocupado com seus próprios interesses? Daí a importância de se investigar, estudar, analisar e discutir: afinal, os juízes estão legislando? E por quê?

\section{ATIVISMO JUDICIAL: SUAS ORIGENS E CONSEQUÊNCIAS}

Iniciar-se-á analisando a base política-jurídica do Estado em que se vive atualmente, um Estado Democrático de Direito, uma junção de grandes conceitos históricos: a democracia e o constitucionalismo. O primeiro tem como base a soberania do povo, já o segundo fundamenta-se na ciência de limitação do poder. Dessa forma, apesar de os conceitos serem aparentemente distintos, a democracia constitucional desde o final do século XX tem se mostrado o melhor regime de governo, o mais adaptado, como se estivesse sempre em uma balança, na qual de um lado está a vontade majoritária e de outro a vontade maior, superior, contida na Constituição.

Não obstante, deve-se observar que tanto a Supremacia Constitucional quanto a jurisdição são mecanismos que foram acionados pelo poder constituinte originário com o intuito de proteger certos direitos e princípios, não mais pelo campo decisório ordinário dos agentes políticos eleitos popularmente, mas pelos instrumentos de controle constitucional das leis e dos atos do Poder Público. Afinal, como disse John Rawls:

a Constituição não é o que a Suprema Corte diz que ela é, e sim o que o povo, agindo constitucionalmente por meio dos outros poderes, permitirá à Corte dizer que ela é. Uma interpretação específica da Constituição pode ser imposta à Corte por emendas, ou por uma maioria política ampla e estável, como ocorreu no caso do New Deal. (apud BINENBOJM, 2004, p. 81)

Complementando tal pensamento, afirmou Eduardo García de Enterría que um dos papéis das emendas constitucionais é o de serem "instrumentos democráticos de correção das decisões da Corte Constitucional incompatíveis com a razão pública” (apud BINENBOJM, 2004, p. 81).

\footnotetext{
${ }^{1}$ Entretanto, faz-se necessário salientar que essa questão da ADPF $\mathrm{n}^{\circ} 54$ que versa sobre a interrupção da gestação de fetos anencéfalos, apesar de ter permitido, ao final do julgamento, o aborto, o STF não agiu como legislador positivo ao tomar tal posicionamento, uma vez que se entende que, na realidade, os princípios fundamentais constitucionais e penais foram apenas protegidos.
} 
No que concerne à jurisdição constitucional, pode-se conceituá-la por meio de dois pontos de vista. O primeiro é que a jurisdição constitucional é uma instância de poder contramajoritário, uma vez que seu objetivo é realmente o de anular atos votados e aprovados, majoritariamente, por representantes eleitos pelo povo. O segundo - o mais aceito hoje - defende que os princípios e direitos fundamentais assegurados pela Constituição são na realidade a essência para o adequado funcionamento da democracia. Sendo assim, quando leis são anuladas por ofenderem a esses princípios ou direitos, tal interferência é em benefício, e não contra, o regime democrático. Portanto, entende-se ser a jurisdição constitucional legítima. Não há de se olvidar que tais direitos e princípios possibilitaram uma maior abertura no processo de interpretação da Constituição, pois além do controle formal, há também o controle abstrato, como também Cappelletti (1999).

Todavia, deve-se tomar os devidos cuidados para que a Corte Constitucional não se torne um poder autoritário composto por um governo de juizes ditando monoliticamente as interpretações ditas oficiais dadas ao texto constitucional. É preciso incentivar a ideia de uma sociedade aberta de intérpretes da Constituição - já timidamente introduzida pela ideia de amigo da corte - ficando a Corte Constitucional de dar a última palavra e não a única, caso contrário, transformar-se-ia "numa instância autoritária e deslegitimada do poder" (BINENBOJM, 2004, p. 248).

O grau de autoridade e de respeito que a Corte terá perante a população variará de acordo com os diálogos com a sociedade em suas decisões. A Constituição Federal de 1988 foi um marco para a democracia por ter ampliado o rol de legitimados para proporem a Ação Direta de Inconstitucionalidade (ADI), o que levou a um considerável desenvolvimento da jurisprudência da Corte a respeito do tema do controle de constitucionalidade. Com um maior acesso ao Supremo Tribunal Federal (STF), a população ficou mais atenta aos seus direitos.

\section{CONCEITO, CARACTERÍSTICAS E IMPORTÂNCIA DO PRECEDENTE JUDICIAL}

É mister estudar acerca das Súmulas Vinculantes, todavia, antes, é importante se ter conhecimentos sobre os precedentes judiciais. Primeiramente, pode-se dizer que, em síntese, precedente judicial é o fato de "a decisão de um caso tomada anteriormente pelo Judiciário, constituir para os casos a ele 
semelhantes" (SOUZA, 2006, p. 51). Segundo o autor, tais precedentes são divididos em declarativos ou criativos; e persuasivos ou obrigatórios.

O precedente declarativo é aquele que somente reconhece e aplica uma norma jurídica já conhecida. Já o criativo não somente aplica, mas também cria uma nova norma. Ambos os precedentes são igualmente importantes, o que fará um ser aplicado em detrimento do outro é apenas a situação.

Faz-se importante observar que todos os precedentes possuem autoridade, entretanto deve-se descobrir qual o grau de tal autoridade, ou seja, até que ponto um precedente influencia a decisão de um juiz em um caso análogo? Critérios como a hierarquia da corte em que proferiu o precedente é levado em consideração, afinal, poderá obrigar tão somente as cortes inferiores a ela, mas não as superiores. Outros critérios também são considerados, a saber: o prestígio do juiz que conduziu a decisão; a data da decisão; a unanimidade ou não; a fundamentação apresentada, dentre tantos outros.

É a partir deste ponto da autoridade, que se classifica os precedentes em persuasivos ou obrigatórios. O primeiro é o caso em que o juiz não está compelido a seguir tal precedente, fazendo-o apenas por livre convencimento. O segundo é quando se observa a vinculação obrigatória por parte do juiz ou corte ao precedente proferido. Além do mais, deve ficar claro que a interpretação precisa ser feita com consciência de que há condições mutáveis, ou seja, decisões antigas podem ser desconsideradas.

O instituto de precedente é observado em qualquer sistema jurídico, seja em sentido aberto ou mais estrito, já que visando os princípios da igualdade, da eficiência e da eficácia, pressiona, de certa forma, o juiz a seguir o precedente, afinal, se o caso é semelhante a um julgado anteriormente, qual o motivo de julgar díspar? No Brasil, pela tradição do civil law, o precedente judicial não deixa de ser um modelo para futuras decisões, a diferença maior para o common law é que o precedente geralmente é persuasivo, e não obrigatório, fornecendolhe uma característica subsidiária no momento em que é confrontado com a norma legislada. No entanto, o precedente judicial obrigatório não é estranho ao sistema brasileiro, uma vez que, com o intuito de garantir a celeridade processual, há alguns tipos de decisões cuja autoridade vincula os órgãos do Judiciário e a Administração.

Sampaio (apud SOUZA, 2006) diz que, ao desenvolver seu objetivo, o Judiciário pode realizar atos desde uma sentença clássica até atos legislativos. Assim, os juízes podem praticar tais atos, de acordo com os seus efeitos, em ordem crescente: sentença clássica e o precedente; sentença normativa com a 
jurisprudência vinculante, os atos quase legislativos e os propriamente legislativos.

No tocante as decisões do Poder Judiciário também se encontra vários tipos: uniformização de jurisprudência que vincula internamente o órgão de tribunal; as decisões com efeito vinculante no controle de constitucionalidade, através das súmulas vinculantes; e até atos quase legislativos, como as sentenças normativas da Justiça do Trabalho e Eleitoral, as quais analisar-se-á no ponto 10 deste artigo o prejulgado trabalhista, a sentença normativa na Justiça do Trabalho, o prejulgado na Justiça Eleitoral e o poder normativo da Justiça Eleitoral.

\section{DAS SÚMULAS E DAS SÚMULAS VINCULANTES}

Este recurso foi adotado pelo judiciário brasileiro com vários objetivos, dentre eles, o de celeridade processual e segurança jurídica. No entanto, apesar dos benefícios, se discute bastante acerca dos poderes atribuídos aos tribunais: será que se está conferindo a estes o poder de legislador? Primeiramente, é importante se fazer uma análise histórica, analisando os momentos que antecederam e corroboraram com o surgimento das súmulas, para em seguida, analisar os efeitos e o alcance das súmulas vinculantes.

\subsection{Surgimento da Corte Constitucional no Brasil e consequências do modelo adotado}

Como no Brasil o modelo adotado foi o de controle misto - concentrado e difuso -, para que suas decisões tenham efeitos a todos, o efeito vinculante é de grande importância e é naturalmente aplicado para que os outros órgãos do judiciário e do Estado no geral, fiquem vinculados a tais decisões.

Na Constituição brasileira de 1824, o Brasil ainda Império, o controle de constitucionalidade era de responsabilidade do legislador: elaborava, interpretava, suspendia e revogava as leis, e ainda guardava a Constituição. Os moldes de controle não eram como os de hoje, o qual só foi implantado na Constituição de 1891, primeira Constituição do Brasil República, todavia, apesar de tal controle já pertencer ao STF, só era dado por via excepcional. O controle jurisdicional das leis também foi estendido aos juízes e aos tribunais - controle difuso tendo assim, o poder de não só conhecer a inconstitucionalidade, mas de resolvêla, afastando a aplicação das leis inconstitucionais. E é na Constituição de 1946, com a emenda 16 de 1965, que é instalado realmente o controle concentrado, elevando-se a apreciação a uma corte constitucional. 
Atualmente, como o Brasil possui o controle misto, é importante saber quais são as possibilidades geradas. O controle difuso permite que:

a) qualquer juiz ou tribunal (este pela maioria dos seus membros ou dos membros do respectivo órgão especial - $\mathrm{CF}$, art. 97) pode apreciar a constitucionalidade de lei ou ato normativo;

b) a apreciação pode ser requerida em qualquer processo, por qualquer das partes, por via de exceção na discussão do caso concreto;

c) como efeito direto e imediato, há a não aplicação da norma tida por inconstitucional somente no caso concreto discutido em juízo, com eficácia, portanto, inter partes;

d) como efeito indireto e mediato, emerge a competência do Senado para suspender a execução, no todo ou em parte, de lei declarada inconstitucional por decisão definitiva do Supremo Tribunal Federal (CF, art. 52, X). (SOUZA, 2006, p. 206)

$\mathrm{E}$, finalmente, o controle concentrado dá-se através das seguintes ações: ADI, ADC (Ação Declaratória de Constitucionalidade), ADPF (Arguição de Descumprimento de Preceito Fundamental), ADI por omissão e ADI interventiva.

\subsection{Conhecendo o efeito vinculante: limites objetivos e subjetivos}

Deve-se observar primeiramente, que efeito erga omnes é diferente de efeito vinculante. Aquele se limita à parte dispositiva; já este é algo a mais, uma vez que a Administração Pública e os órgãos do Poder Judiciário - exceto o STF - devem se submeter às decisões proferidas nas ações diretas, caso contrário, há um instituto próprio, a Reclamação, a qual solicita ao STF que garanta, prontamente, a autoridade de sua decisão. É preciso atenção para não confundir os conceitos.

Assim, é importante conhecer quais seriam, pois, os limites do efeito vinculante. Primeiramente, dividir-se-á tais limites em objetivos e subjetivos com o intuito de um melhor entendimento. Nos aspectos objetivos, podem-se tirar dois pensamentos principais: um mais restritivo, que diz ter a vinculação alcance apenas no dispositivo da decisão; no entanto, outro pensamento mais aberto defende tal efeito ir além da parte dispositiva alcançando até os fundamentos determinantes da decisão, observando uma maior preocupação com o conteúdo normativo do que com a forma. 
$\mathrm{Na}$ prática, as sentenças que têm como intuito "interpretar" para responder a uma necessidade social, acabam construindo uma interpretação concreta divergente da literalidade do texto legal, fazendo surgir quase uma nova norma, de maior ou menor abrangência do que a realmente posta pelo legislador. Às vezes, esta nova norma não está nem na parte dispositiva da sentença, mas nos fundamentos jurídicos (AJA; BEILFUSS apud SOUZA, 2006, p. 222).

Deve-se entender que o controle abstrato das normas tem especificidades diferentes do controle de casos concretos que ocorre nos países de common law cuja doutrina é do stare decisis. Por exemplo, sendo declarada inconstitucional uma lei estadual, por quais motivos não se deve decretar inconstitucionais também as leis idênticas de outros estados? Assim, para economia de tempo e de recurso, e para garantir a igualdade no tratamento de circunstâncias semelhantes, o fundamento da decisão da ação direta deve abranger ambas as situações com efeito vinculante. Sendo assim, os efeitos devem ir além da parte dispositiva - adota-se aqui a teoria mais aberta -, impondo força da lei. Dessa forma, no Brasil, o precedente é aplicado também aos atos normativos idênticos.

No que concerne aos limites subjetivos, a discussão é ainda mais polêmica, a qual se detém a dois pontos: o primeiro é se a decisão decorrente de ação direta vincula também o Poder Legislativo, estando este, em regra, proibido de editar normas de igual conteúdo; o segundo é se tal decisão de ação direta vincula também o próprio STF, o qual não poderia contemplar novamente a lide e, se necessário, também não teria permissões de proferir sentença contrária.

\subsubsection{A decisão de ação direta e o legislativo}

Para responder ao primeiro ponto, é interessante analisar a princípio a doutrina de alguns países europeus de significativa importância para o direito brasileiro. Na Alemanha, por exemplo, a regra é que o Poder Legislativo está sim, vinculado à decisão proveniente de ação direta. Assim, como defende Weber (apud SOUZA, 2006, p. 255), lá o efeito vinculante quer dizer que o legislador está proibido de aprovar uma norma que já fora declarada inconstitucional e não pode também repetir erro constitucional já praticado.

Consoante Souza (2006), na Itália não há uma norma escrita que obrigue a vinculação do legislativo, mas é facilmente deduzido a partir de princípios do 
sistema institucional feito pela Constituição, com o objetivo de manter a inteireza do guardião da Constituição. Já em Portugal, acredita-se que o legislador também está vinculado, conquanto que não tenham sido modificadas as circunstâncias motivadoras do juízo da ação direta, afinal, a revisão deve ser exigível ou, pelo menos, cabível.

Todavia, no Brasil, o entendimento predominante é o contrário e defendem que a Emenda Constitucional no 03 de 1993 (EC 03/93) é clara ao vincular apenas os órgãos do judiciário - exceto o STF - e a Administração Pública, ficando de fora o legislativo. E um dos primeiros argumentos trazidos por Cappelletti (1999) é que tal vinculação ao Poder Legislativo estaria colocando em jogo o conceito basilar assegurado pela Constituição da separação das funções do poder.

Essa ideia, entretanto, pode ser refutada, uma vez que tal teoria hodiernamente não é mais vista com tamanha rigidez, pois, se assim o fosse não seria permitido o controle de constitucionalidade das leis pelo judiciário. Portanto, não se emprega mais a rígida separação entre os poderes preconizada por Aristóteles e formulada por Montesquieu, como já foi visto anteriormente (ponto 3.2), porque apesar de ser essencial para a atuação do poder político, não é um dogma da democracia, mas "uma receita de liberdade cujo valor prático depende das circunstâncias" (FERREIRA FILHO apud SOUZA, 2006, p. 48).

\subsubsection{A decisão de Ação Direta e a Corte Constitucional}

Outro argumento utilizado é em respeito à falta de um texto constitucional que expresse tal vinculação do Poder Legislativo. Ademais, como foi anteriormente observado o posicionamento italiano, não é necessária a existência de uma norma expressa defendendo tal situação, uma vez que se pode tirar tanto da constituição brasileira quanto da italiana, que o próprio papel desempenhado pela Corte Constitucional de guardiã da Constituição, permite que ela profira a última palavra acerca da constitucionalidade. E, nada mais lógico e natural que o legislativo se vincule a tal decisão, desde que o conteúdo e as situações sejam idênticos. Portanto, se uma norma já foi declarada inconstitucional porque repetir tal erro novamente? E aí sim, ferir a Carta Magna? Se não houver mutação, não há sentido em mudar o julgamento.

É importante ainda deixar claro que não se está tirando do legislador a capacidade de ir ao encontro da decisão do STF - até porque a natureza do 
processo legislativo impede isto -, uma vez que como já foi dito, permite-se edição de lei ao se mudar os fatos, como uma mudança substancial das relações fáticas ou da percepção jurídica geral.

A partir de tais ideias já apresentadas aqui é possível até responder ao segundo ponto - a decisão na ação direta vincula o próprio STF que não pode mais apreciar de novo a questão, sendo o caso, até decidir em sentido oposto ao da sua decisão anterior? À primeira parte da indagação, a resposta é NÃO, já que a Emenda ${ }^{\circ} 3$ de 1993 afirma o efeito vinculante ter força para com os "demais órgãos do Poder Judiciário". Já no que diz respeito à segunda parte da pergunta pode-se dizer que, em regra, não, ou seja, o STF não poderia reapreciar o caso dando-lhe conotação divergente da empregada anteriormente, mas é ressalvado nos casos de mutação constitucional, tendo primeiramente de convencer que se trata de uma nova questão.

\subsection{A origem da súmula no Brasil e o intuito de sua implantação}

Daí, pelo ano de 1960, surgiu a súmula no Brasil, uma vez que o STF estava lotado com amontoamento de vários processos à espera de julgamento, a maioria deles tratando sobre questões idênticas. Assim o STF alterou seu regimento (1963) e publicou oficialmente a Súmula de sua jurisprudência depois de demorado e trabalhoso processo de construção.

É mister salientar que a adoção da súmula vai muito além de simples motivos como economia de tempo e agilidade, mas também da certeza do direito, já que sendo a jurisprudência sólida - mas não imutável - do tribunal contribui-se com a segurança jurídica; da previsibilidade pois deixa ao alcance de todos a previsão de decisão até de lides futuras; da igualdade permitindo uma menor variação da interpretação sobre determinada questão. Apesar de a origem da Súmula ter sido primeiramente, regimental, depois com o Código de Processo Civil de 1973 é que houve previsão legal e permitiu o uso das súmulas para os demais tribunais também: "O julgamento, tomando pelo voto da maioria absoluta dos membros que integram o Tribunal, será objeto de súmula e constituirá precedente na uniformização da jurisprudência." (art. 479, CPC).

Não há de se negar que a constitucionalização da súmula representou um novo momento que rompeu com a tradição observada nos países de Civil $L a w$ de forte ligação com a norma legislada. Além do mais, é importante salientar a diferença de súmula e o precedente obrigatório: neste, faz presente a força vinculante; já naquela, tal força vinculante abrange apenas o próprio tribunal 
emitente, e para os outros órgãos judiciais seu valor é tão somente persuasivo. Entretanto, na prática, se vê que as súmulas do STF e do STJ são praticamente tratadas como incontestáveis.

\subsection{O tipo de súmula escolhido pelo Poder Judiciário brasileiro}

A súmula pode ser de diversos tipos: declaratório, o qual reproduz o texto legal; intra legem, que já existindo uma norma que regulamente o caso, se interpreta dentro dos limites já trazidos pela lei; e extra legem, que preenche espaços vazios ou aumenta os limites previamente deixados pela lei. Em regra, quando tal lei deixa de existir ou é modificada, a súmula também deve ser, entretanto, há exceções, desde que a súmula esteja ligada aos princípios, e não a lei em si.

A partir de tais experiências decidiu-se adotar a súmula vinculante, trazida do cotidiano de outros países, o que é muito importante por representar a intersecção dos sistemas Common Law e Civil Law complementando-se um ao outro. Tal adoção se deu pela Proposta de Emenda à Constituição n ${ }^{\circ} 29$ de 2000 (PEC 29/00) - a famosa Reforma do Judiciário - a qual foi aprovada com uma ressalva: apenas o STF pode utilizar-se de tal súmula e ainda na esfera de sua competência em matéria constitucional. Além do mais, os efeitos apenas serão produzidos se pelo menos dois terços $(2 / 3)$ dos integrantes do STF concordarem e, por conseguinte, deve haver publicação na imprensa oficial. A partir da súmula vinculante esperou-se que a demanda processual fosse reduzida.

É claro ainda que o Poder Legislativo no exercício típico de sua função, não está, em regra, vinculado pela Súmula. Afinal, a reforma do judiciário, a priori, não criou uma supremacia do Poder Judiciário sobre o Legislativo, assim, este não precisa concordar com as súmulas vinculantes. Todavia, há de se anuir na tamanha insegurança jurídica e incerteza do Direito, haja divergências. Nesses moldes, poderia o STF - de ofício ou provocado - entrar com ação de inconstitucionalidade sem nulidade da norma antes mesmo de a lei ser promulgada ou aprovada, por exemplo? (MENDES, 1998).

A Súmula pode também ser revisada pelo próprio STF, de ofício, desde que em dissonância com o Direito, ou ainda, cancelada. Com certeza a súmula vinculante representa um grande avanço judicial, mas não é um "remédio milagroso" para todos os males. É necessária também ação do Poder Legislativo. 


\section{O JUIZ COMO LEGISLADOR ATÍPICO}

Após esses estudos e análises históricas do direito brasileiro e de alguns exemplos de outros países, é preciso se entender porque o juiz legisla, mesmo que tal função seja de forma excepcional e que deva ser, ao máximo, evitada. Porém, o que o leva a tal posicionamento são as circunstâncias jurídicas, fáticas e políticas. A polêmica aumenta porque para alguns, certas práticas vão além do permitido na Carta Magna. No entanto, não se deve esquecer que o poder é uno e que a teoria dos Freios e Contrapesos é base do sistema constitucional garantista brasileiro.

\subsection{Interpretar criando o direito}

No momento em que o juiz aplica uma lei, está exercendo certa discricionariedade e, portanto, está se utilizando de criatividade - embora limitada -, pois sempre haverão lacunas deixadas pelo legislador, as quais deverão ser preenchidas pelo juiz, retirando qualquer dúvida ou ambiguidade. Ou seja, inferese que, quando o juiz interpreta, está se utilizando de certo grau de criatividade. É mister salientar que interpretar é compreender além das palavras ali escritas, é desvendar o seu sentido e alcance de suas expressões através de uma análise sociocultural do respectivo momento histórico. Afinal, como afirma Bemfica (1995, p. 21): "não lhe basta [ao juiz] ser fiel aplicador da lei. Essa qualquer pessoa pode aplicar, porque, segundo Maggiore, citado por Laércio da Costa Pellegrino, 'o fim a atingir-se não é a aplicação da lei, é a atuação da justiça'”.

A interpretação é banhada pela subjetividade, como se entende hoje majoritariamente, dependendo muitas vezes das concepções que cada ser possui. E de tal questão surge o problema-central: até que ponto os juízes estão se utilizando de tal criatividade? Quais são os limites, os modos para a aceitação dessa prática? No seu labor, os juízes têm o poder de escolha conforme a sua interpretação em cada caso. Tanto a lei quanto qualquer interpretação que tenha como objeto a linguagem e as palavras estão sujeitas a mutações de significado, sendo o tempo, por exemplo, um dos principais fatores de mudanças de sentido.

É necessário fazer uma ressalva de que os juízes são - e devem ser limitados processual e substancialmente, apesar de sua arbitrariedade (liberdade judicial). Entretanto, nem sempre é preciso haver obediência ao "princípio da sujeição à lei” para que haja jurisdicionalidade, já que não é um requisito essencial 
para a decisão. Mais do que está escrito na lei, alguns juízes possuem o poder de basear suas decisões na equidade, por exemplo. Sendo assim, é de elevada importância estudar quais os modos, limites e legitimidade para a criação do direito pelos juízes. Afinal, criatividade é diferente de total liberdade.

A atividade do juiz ligada à lei muito se confunde com a do legislador. O poder deste está vinculado não apenas à Carta Magna escrita, mas também às decisões judiciais ligadas aos assuntos constitucionais. Consoante a óptica de Cappelletti (1999), a criatividade do legislador pode até ser mais frequentemente recorrida - o que não é visto no Brasil ${ }^{2}$-, porém um não é qualitativamente inferior ou superior ao outro. Ou seja, ambos participam de processos de criação do direito.

\subsection{Criar o direito versus legislar}

Esta pergunta não é fácil de ser respondida, pois envolvem limites tão peculiares e subjetivos que se torna complicado separar um conceito do outro, de diferenciá-los. Mesmo assim, uma parte da doutrina entende que são conceitos diferentes, já a outra defende estarem estes ligados de forma tão intrínseca que a separação não é possível.

\subsubsection{O plano processual como distinção}

Analisou-se até o presente momento a tamanha criatividade, ativismo e vinculação que circundam o judiciário e os motivos para a existência e necessidade de tais características. A partir de tal ideia formulada e discutida, chega-se à seguinte indagação: afinal, os juízes legislam? Ou seja, usurpam as funções do Poder Legislativo?

Alguns autores, como Cappelletti (1999), defendem que interpretar, esclarecer e transformar não significa legislar, sendo preciso analisar a diferença

\footnotetext{
${ }^{2}$ Conforme o Congresso em foco, Gilmar Mendes já chegou ao ponto de acusar demora do Congresso Nacional por "inércia" do Parlamento. Além de acusações por parte de Randolfe Rodrigues (2010) senador pelo Amapá - de que parlamentares com funções de comando ignoram determinados procedimentos legislativos.

Semelhantemente, Navanethem Pillay, comissária da ONU (Organização das Nações Unidas) no que diz respeito aos Direitos Humanos, criticou a demora do Congresso Nacional em aprovar projetos de lei nessa área, citando até a existência de textos que versam sobre os índios e a Amazônia que tramitam há mais de dez anos. Informações em Laboissière (2009).

E, a sociedade brasileira, conforme pesquisa da Fundação Getúlio Vargas (CUNHA et al., 2012), não confia no Congresso Nacional: o grau de confiança nesta instituição é o segundo menor, apenas $22 \%$.
} 
entre os processos legislativo e jurisdicional: do ponto de vista substancial, ambos os processos teriam como resultado a criação do direito, entretanto, o modo, o procedimento, é o que os distinguiria. Conforme o entendimento de Cappelletti (1999), o juiz até pode ser ativista, mas não pode agir como um legislador, senão deixaria simplesmente de ser juiz. Assim, a legislação seria apenas uma forma de criar o direito, fundamentalmente divergente do judiciário.

Entendem ainda que, na prática, as seguintes características (no plano processual, e não no substancial) diferenciam tais poderes:

a. Atividade decisória com as partes do caso concreto

b. A imparcialidade do juiz que deve assegurar o direito das partes serem ouvidas

c. Grau de suficiência e independência tal que não ceda a pressões externas - em especial às políticas.

No entanto, é importante ressaltar que mais à frente se perceberá que todas estas três características, expressas por Cappelletti (1999) como a diferença essencial entre legislativo e judiciário, podem ser refutadas, tendo por base as seguintes ideias-chave: precedentes e súmulas vinculantes; a imparcialidade do legislador com a prática da boa política (RODRIGUES, 2010) e a ausência de caso concreto e do contraditório em alguns processos, como o Eleitoral; e fenômeno de politização do judiciário.

Dessa forma, complementa Cappelletti (1999) que a diferença entre o legislativo e o judiciário está essencialmente no procedimento, ou seja, é o modo do processo jurisdicional. Modo tal que, simultaneamente, é uma grande virtude da função jurisdicional, e são também as limitações de tal função. Portanto, para ele, quando não houver a estreita conexão entre o parecer e o caso concreto a ser resolvido, os tribunais não estarão agindo como juízes, mas como legisladores ou administradores, pois as divergências anteriormente apresentadas seriam os contornos essenciais da função jurisdicional.

\subsubsection{A realidade do "make new law"}

Explicar na teoria como se dá a interpretação de uma lei é fácil se comparado ao esclarecimento de como os juízes, realmente, decidem os casos sob sua responsabilidade.

Cardozo (apud SOUZA, 2006, p. 35) afirma que alguns autores insistem em defender a ideia de que os juízes em momento algum legislam, ou seja, era 
como se uma norma estivesse lá, fincada, mas camuflada, e os juízes tirassem os disfarces e mostrassem a lei a todos. Dessa forma, ao se rejeitar o pensamento de que o Direito nunca pode ser feito por juízes, alguns de seus defensores acabaram por concluir que o Direito nunca é feito pode ser outrem. Já caso se acredite que os juízes constantemente legislam pode chegar a uma ideia errônea de que mesmo as leis em sentindo estrito não são direito, uma vez que os tribunais necessitariam formar sua acepção. Assim, deve-se buscar a harmonia dos dois raciocínios apresentados.

Cardozo segue ainda dizendo que uma das realidades da vida é a criação do Direito pelo juiz, e indaga: "onde o juiz encontra o Direito que incorpora em seu julgamento?" (apud SOUZA, 2006, p. 36). E, em seguida, responde que há casos em que a fonte é evidente, pois a regra provém da Constituição ou da lei, mas afirma que os códigos e as leis não constroem um juiz supérfluo e nem automatizado, havendo, assim, lacunas, dúvidas e ambiguidades a serem preenchidas e esclarecidas.

E, é a partir deste trabalho de preencher lacunas que o juiz, para poder resolver um caso em que não existe uma garantida referência preexistente, tem que proferir decisões que criam algo novo, o que ele chama de "make new law". O juiz não é um mero descobridor do Direito, mas um criador de um Direito novo, tanto é que há muitas áreas do Direito que só existem por decisões judiciais (Jacqueline Martin apud SOUZA, 2006, p. 45), como a Eleitoral e a Trabalhista.

Segundo o positivismo, os juízes deviam ser neutros, limitandose formalmente a compatibilidade entre lei e Constituição. Não existia espaço para a construção judicial através de uma atividade criativa do juiz. Portanto, sob a óptica desta escola, a decisão é a exteriorização da vontade do legislador, e não da Corte Constitucional que a pronunciou. No entanto, toda atividade judicial, principalmente as de natureza constitucional têm uma essência criativa, adaptando a frieza normativa a situações mais específicas dentro de um espaço de conformação cada vez mais aberto e abstrato.

Kelsen defende que a função desempenhada pela Corte Constitucional se parece mais com a de um legislador negativo ao comparar o controle de constitucionalidade a uma modalidade especial de revogação da lei (apud BINENBOJM, 2004, p. 69). Além do mais, Carl Schmitt assegura que o Tribunal Constitucional, na realidade, decide o que é a Constituição mais do que tão somente a aplica: ele não repete o direito, ele o constrói. 
Tal fato é observado devido ao desenvolvimento exacerbado da jurisdição constitucional que leva ao processo de politização da Justiça. Como disse Carl Schmitt (apud BINENBOJM, 2004, p. 70), "a política não tem nada a ganhar e a Justiça, tudo a perder".

Como constatado por Kelsen, a jurisdição envolve mais atividades volitivas do que cognitivas, gerando um confronto: como harmonizar a função do Tribunal Constitucional - basicamente repleto de jurisprudência criativa e construtiva - com a função dos legisladores? Ou seja, como não haver comprometimento nem da soberania popular nem da supremacia constitucional?

Deveria ser estabelecido um campo próprio de atuação da Corte, além de limites que possam distanciá-lo da área a ser completada pelos legisladores, uma vez que os juízes são mais qualificados para solucionar questões principiológicas; e os legisladores, para propor as políticas públicas que mais atinja o interesse social.

Não se quer defender um governo autoritário de juízes, mas um ativismo judicial construtivo ao se legislar - seja negativamente ou positivamente -e ao se permitir a revisão judicial. Dessa forma, a Lei Fundamental estaria sendo protegida de corrosão perante a legislação muitas vezes temporária ou repleta de interesses particulares, pontuais e poderosos. Vale ressaltar que ao se falar em legislador negativo está se referindo a um órgão capaz de afastar do ordenamento jurídico brasileiro as normas inconstitucionais.

Uma das funções da Emenda Constitucional é a de corrigir decisões da Corte Constitucional conflitante com a razão pública, como já foi dito. Dessa forma, a função da Corte vai bem além da função de legislador negativo enquanto guardião da integridade sistêmica do ordenamento jurídico. Sua missão é de proferir o debate público consoante os princípios constitucionais, "coagindo" o legislador a levá-los em conta durante o processo democrático.

É importante deixar claro que, cotidianamente há criação de Direito, através de elaboração e promulgação de leis, no sentido estrito, uma vez que o sistema jurídico por enquanto que a sociedade continue dinâmica, nunca estará finalizado, precisando sempre evoluir. Com as decisões jurídicas não é diferente, pois o sistema permanece inteiro - para todas as questões jurídicas surgidas há de se encontrar solução -, entretanto quando são proferidas decisões que reincidem sobre tema em que não há legislação, aí, possivelmente, foi criada uma nova norma. 


\section{O POSICIONAMENTO DO STF QUANTO AOS PODERES DO JUDICIÁRIO}

É de extrema importância analisar três "decisões-chave" do STF de anos diferentes em ordem crescente para se constatar também na prática a evolução da dicotomia: judiciário e legislador. Pinheiro (2006) explica a importância da apreciação dessas Ações Diretas de Inconstitucionalidade em consonância com pesquisa construída com 59 (cinquenta e nove) decisões:

A análise da ADI-MC 896 se justifica pelo fato de ela expressar a forma mais comum da utilização do argumento pelo Tribunal nas 59 decisões encontradas. (...) A análise da ADI 1.949 mostra uma profunda alteração no posicionamento do Tribunal em relação ao argumento. Por fim, a ADI 3.459 é a última decisão até o momento em que há uma discussão a respeito do tema [STF como legislador negativo] e sua análise permite fazer digressões críticas para o futuro desenvolvimento do argumento (PINHEIRO, 2006).

\subsection{ADI-MC 896}

A primeira decisão selecionada foi a de ação direta de inconstitucionalidade, ADI-MC 896 (DISTRITO FEDERAL, 1993), cujo julgamento se deu em 03 de Novembro de 1993, provocada pelo Procurador Geral da República requerendo que fosse declarada a inconstitucionalidade dos artigos 270, caput, parágrafos $1^{\circ}$ e $2^{\circ}$, e da expressão "não alcançados pelo artigo anterior" do caput do artigo 271, ambos da Lei Complementar (LC) $n^{\circ} 75 / 93$, com base nos artigos $5^{\circ}$, inciso XXXVI e 93, inciso II da CF, defendendo a ideia de que tal LC estaria criando um critério novo de promoção de Procuradores, um critério arbitrário de tempo, o que não é englobado nem pelo de antiguidade nem pelo merecimento previsto na $\mathrm{CF}$. Portanto, entendeu o autor da ADI que partes da LC seriam inconstitucionais. Diz esta lei que:

Art. 270. Os atuais Procuradores da República de $1^{\text {a }}$ Categoria, que ingressaram na carreira até a data da promulgação da Constituição Federal, terão seus cargos transformados em cargos de Procurador Regional da República, mantidos seus titulares e lotações.

$\S 1^{\circ}$ Os cargos transformados na forma deste artigo, excedentes do limite previsto no artigo anterior, serão extintos à medida que vagarem. 
$\S 2^{\circ}$ Os Procuradores da República ocupantes dos cargos transformados na forma deste artigo poderão ser designados para oficiar perante os Juízes Federais e os Tribunais Regionais Eleitorais.

Art. 271. Os cargos de Procurador da República de $1^{\text {a }}$ Categoria não alcançados pelo artigo anterior e os atuais cargos de Procurador da República de $2^{\mathrm{a}}$ Categoria são transformados em cargos de Procurador da República. (LC nº 75 de 1993, grifo nosso). (DISTRITO FEDERAL, 1993).

O ministro relator Moreira Alves defende que tal pedido não pode ser aceito em decorrência de que o Tribunal não pode criar norma que o legislador não criara, e nem ir de encontro a este. Desta forma, não permitindo a transformação de cargos de Procurador da República em cargos de Procurador Regional da República, como declara a lei. Assim, Moreira Alves desconhece a ação e extingue o processo sem julgamento do mérito devido a impossibilidade jurídica do pedido. E complementa ainda esclarecendo que a possibilidade jurídica é justamente um dos pré-requisitos para a ação direta.

Houve ainda uma contra-argumentação feita pelo ministro Marco Aurélio que diz e defende que o Tribunal não estaria legislando ao aceitar tal ação. Mas, por maioria, o processo é extinto sem julgamento do mérito.

Esta decisão mostra o posicionamento do Tribunal no que diz respeito à alteração do sistema jurídico ao conferir validade a uma norma não feita pelo legislador ordinário. Na verdade, há um empecilho em modificar o próprio texto normativo a partir da supressão de fragmentos. Como já visto alguns nomeiam tal prática - hoje natural - de ativismo judicial, outros de legislação negativa, e outros ainda de legislação.

O temor de o juiz usar a criatividade era tamanho que se pode ver que neste momento do início da década de 1990 era proibido de a Corte retirar do ordenamento jurídico qualquer dispositivo de lei, pois a inovação era papel do legislador. Daí se indaga: e a função do Tribunal de controle judicial de constitucionalidade?

\subsection{ADI-MC 1949}

A segunda decisão escolhida foi também uma ADI-MC 1.949 que foi julgada em 18 de novembro de 1999 e proposta pelo Governador do Estado do Rio Grande do Sul pedindo que o STF declarasse inconstitucionais os artigos $7^{\circ}$ e $8^{\circ}$ da lei estadual $n^{\circ} 10.931 / 97$, alterados pela lei estadual $n^{\circ} 11.292 / 98$ : 
Art. $7^{\circ}$ : O Conselheiro terá mandato de 4 (quatro) anos, será nomeado e empossado somente após a aprovação do seu nome pela Assembleia Legislativa do Estado, devendo satisfazer, simultaneamente, as seguintes questões.

Art. $8^{\circ}$ : O Conselheiro só poderá ser destituído, no curso de seu mandato, por decisão da Assembleia Legislativa. (Grifo nosso)

O autor argumenta que a lei em debate, ao criar a Agência Estadual de Regulação de Serviços Públicos Delegados do Rio Grande do Sul (AGERGS) estaria criando nova entidade ligada ao Poder Executivo do RS. Assim, apenas o chefe do Poder Executivo é quem teria o poder de exonerar os dirigentes desta nova entidade, e não a Assembleia Legislativa, por decisão imotivada, como previsto na lei. Requerendo-se, assim, a aplicação dos artigos 25, caput, e 84, inciso XXV da Constituição Federal.

A princípio, o relator, ministro Sepúlveda Pertence, posicionou-se a favor de suspender todo o artigo $8^{\circ}$. No entanto, o ministro Nelson Jobim defende que o recebimento da ação na forma pedida pelo autor - de retirar eficácia de parte do artigo $8^{\circ}$ - faria o Tribunal legislar positivamente. E, finaliza invocando a impossibilidade jurídica de a Corte conhecer a ação.

Depois de muitas discussões, se permite que o proponente edite seu pedido para que o STF analise novamente. Agora, a ADI é estendida para que se suspenda o artigo $8^{\circ}$ da referida lei estadual por completo.

Durante a votação se começa a perceber certo consenso sobre a inconstitucionalidade do artigo $8^{\circ}$. Em seguida, o ministro Néri da Silveira faz uma pergunta interessante: caso o artigo $8^{\circ}$ seja declarado inconstitucional e, assim, retire sua eficácia, qual é a hipótese de incidência da demissibilidade de Conselheiro da AGERGS? O próprio ministro já soluciona: que ao se declarar a inconstitucionalidade do referido artigo, o conselheiro da AGERGS só perdesse seu cargo na hipótese de cometer falta grave. O ministro nomeia esta cláusula de "cláusula enquanto bem servir". Mas nasce outra pergunta: como fundamentar esta cláusula na lei estadual $10.931 / 97$, se ela não foi conjecturada anteriormente pelo legislador?

E, foi para encontrar uma solução que se conjeturou utilizar a expressão "interpretação conforme a constituição". Entretanto os ministros não aceitaram por acreditarem não se poder modificar o sentido da norma sem a redução do texto. Outra ideia surge: a da existência de um vazio legislativo; um "buraco negro" no qual não existiria norma aprovada pelo Poder Legislativo que complementasse a necessidade de alguma hipótese de incidência. Percebeu- 
se ainda que este "buraco negro" seria mais inconstitucional do que a própria inconstitucionalidade da lei, assim, a partir de então se depreende que as normas infraconstitucionais podem ter divergentes graus de inconstitucionalidade.

$\mathrm{Na}$ Alemanha, por exemplo, a Corte Constitucional pode declarar a inconstitucionalidade de certo dispositivo normativo ao Congresso Nacional e obrigá-lo, em assentado prazo, a preencher o vazio normativo que se formaria através da declaração de inconstitucionalidade. Mas no Brasil ainda não se tem este artifício. No caso que está sendo julgado, a solução inovadora foi justamente o da "cláusula enquanto bem servir".

O ministro Marco Aurélio é contra tal cláusula, uma vez que esta solução implica na criação de nova norma não recebida pelo Legislativo e não trazida pela Constituição. Dá-se início a discussão acerca do legislador negativo. Alguns ministros rebatem defendendo a flexibilização e argumentam que a função jurisdicional de uma Corte Constitucional não se sintetiza ao simples afastamento das normas inconstitucionais, mas também se concretiza fixandose novas normas, nem que sejam transitórias, as quais irão viger até que o próprio legislador não complete os vazios normativos. Este último argumento vence e o dispositivo do Acórdão é escrito da seguinte forma:

[...] e, por maioria de votos, em deferir o pedido de medida liminar, para suspenderem até a decisão final da ação direta, a eficácia do art. $8^{\circ}$ da Lei estadual n. ${ }^{\circ} 10.931$, de 9.01.97, na redação que lhe deu o art. $1^{\circ}$ da Lei estadual n. ${ }^{\circ} 11.292$, de 23.12.98, assim como na sua redação original, sem prejuízo de restrições à demissibilidade, pelo Governador do Estado, sem justo motivo, consequentes da investidura a termo dos Conselheiros [...] e também sem prejuízo da superveniência de legislação válida. (ADI-MC 1.949). (NUNES, 2009).

A partir desta decisão depreende-se que foi emitida realmente nova regra sobre a demissibilidade dos Conselheiros da AGERGS, neste momento, eles só podem ser demitidos pelo Governador do Estado do RS por decisão motivada. A dúvida que ainda ficou era se o caso devia ser tratado como de controle concentrado ou difuso.

É importante perceber que tal decisão significou a quebra da rejeição outrora apresentada pelo STF em assumir sua atividade criativa. E, entende-se que quando o Judiciário declara norma inconstitucional, normalmente finda mudando o sistema jurídico, criando normas antes não previstas nem pelo 
legislador ordinário, nem pelo constitucional. Dessa forma, o STF formula precedente para casos futuros semelhantes.

\subsection{ADI 3459}

A terceira decisão selecionada foi uma ADI 3.459 (RIO GRANDE DO SUL, 2005), julgada em 24 de Outubro de 2005 cujo proponente foi o Governador do Estado do Rio Grande do Sul contra dispositivo de lei estadual. O próprio Governador propôs esta lei prevendo um reajuste salarial de 1\% a todos os servidores públicos do RS, o que está assegurado pelo artigo 37, inciso X, da CF. A lide surgiu quando o projeto de lei passou pela Assembleia Legislativa do Estado e foi modificado, acrescentando-se o termo "do Poder Executivo":

Art. $1^{\circ}$ Ficam revistos, na forma do inciso $\mathrm{X}$ do art. 37 da Constituição Federal e do $\S 1^{\circ}$ do art. 33 da Constituição Estadual, em 1,0\% (um por cento), a partir de $1^{\circ}$ de setembro de 2005, as remunerações e subsídios de todos os servidores e agentes públicos do Poder Executivo do Rio Grande do Sul, suas autarquias e fundações públicas (grifo nosso). (RIO GRANDE DO SUL, 2005).

O governador defendia que tal alteração não seria possível de ser feita pela Assembleia Legislativa em função do artigo 37, inciso X, da CF que dá a competência exclusiva ao chefe do Poder Executivo de estabelecer o valor de reajuste salarial para todos os servidores públicos. Pedindo assim, a declaração de inconstitucionalidade da expressão “do Poder Executivo" do artigo $1^{\circ}$ da lei estadual já citada.

Ao começar a fase de argumentação, iniciam também as dúvidas, e a primeira foi: será que ao declarar a inconstitucionalidade do termo "do Poder Executivo", a Corte Constitucional estaria legislando positivamente? Já que, é claro o alargamento do campo de incidência da norma a casos que o legislador estadual não expressara desejos.

Em seguida, por unanimidade, chega-se a conclusão de que eliminar a expressão, abrange os efeitos da lei, pois cria norma que o legislador estadual não previra. O debate a partir de então é para se saber se o STF deve fazer isto neste caso ou não. A maioria do tribunal pensa como o relator, ministro Marco Aurélio: 
A questão que se coloca: se o Supremo, na apreciação desta ação direta de inconstitucionalidade, expungir esta expressão [do Poder Executivo], estará substituindo-se à Assembleia? A resposta, para mim, é desenganadamente positiva. Estará aprovando o que a Assembleia não aprovou; ao contrário rejeitou. Por isso, penso que, aqui, surge a impossibilidade jurídica do pedido. (RIO GRANDE DO SUL, 2005, p. 47).

Todavia, há opiniões contrárias, como a do ministro Gilmar Mendes que contesta que ao STF não deve ser, obrigatoriamente, proibido de a Corte legislar positivamente, devendo, portanto, aceitar o pedido, uma vez que já é um dogma superado por outras cortes constitucionais e que também deve ser vencido pelo STF.

\section{SÚMULA VINCULANTE $\mathbf{N}^{\circ} 11$}

A partir dessas três decisões no sentido de conhecer o pensamento vigente no STF em cada momento, analisar-se-á uma polêmica súmula vinculante, a de número 11. Como já foi dito, a Súmula com efeitos vinculantes foi introduzida no ordenamento jurídico brasileiro com a EC 45/2004 e se exigiu alguns critérios para sua criação (artigo 103-A, lei 11.417 de 2006), dentre eles está: "a súmula é um entendimento da maioria dos ministros do STF a respeito de alguma norma preexistente." (SILVA, 2008). Tal exigência é constatada no parágrafo $1^{\circ}$ do artigo $2^{\circ}$ da Lei 11.417 que tem redação idêntica à do artigo 13-A da CF:

Art. $2 .^{\circ}[\ldots] \S 1^{\circ} \mathrm{O}$ enunciado da súmula terá por objeto a validade, a interpretação e a eficácia de normas determinadas, acerca das quais haja, entre órgãos judiciários ou entre esses e a administração pública, controvérsia atual que acarrete grave insegurança jurídica e relevante multiplicação de processos sobre idêntica questão.

Agora é necessário analisar a Súmula Vinculante (SV) n ${ }^{\circ} 11$, aprovada por unanimidade e publicada no Diário Oficial em 22 de Agosto de 2008:

Só é lícito o uso de algemas em caso de resistência e de fundado receio de fuga ou de perigo à integridade física própria ou alheia, por parte do preso ou de terceiros, justificada a excepcionalidade por escrito, sob pena de responsabilidade disciplinar, civil e penal do agente ou da autoridade e de nulidade da prisão ou do ato processual a que se refere, sem prejuízo da responsabilidade civil do Estado. 
Assim, indaga-se: qual foi a norma preexistente escolhida pelo STF para a constitucional interpretação? A decisão foi baseada nos artigos $1^{\circ}$, III e $5^{\circ}$, III, X e XLIX, todos da Constituição Federal; o art. 350 do Código Penal; o art. 284 do Código de Processo Penal; o art. 4º, a, da Lei 4.898/65 e o art. 234, $\S 1^{\circ}$ do Código de Processo Penal Militar. Todavia, o artigo 199 da Lei de Execução Penal (Lei 7.210/84) afirma que "o emprego de algemas será disciplinado por decreto federal". Sendo assim, qual o decreto foi editado a respeito do uso de algemas? Nenhum.

Infelizmente, o Legislativo vem se omitindo em dar tratamento legal para assuntos polêmicos e concernentes à dignidade da pessoa humana e, consequentemente, o STF vem legislando atipicamente para defender os direitos humanos, afinal, não é de se esperar pelo legislador ad eternum. Lembrando ainda que não há nenhuma vedação expressa na Constituição no que diz respeito a atuação dos juízes como legisladores, assim também como não há nenhum que os autorize a suprir as lacunas vinculando.

Especificamente, o trecho "[...] justificada a excepcionalidade por escrito" da SV n ${ }^{\circ} 11$ deixa ainda mais claro que o ST foi além de interpretar e aplicar princípios, mas legislou, tanto é que além de modificar o ordenamento jurídico com seu ato normativo, impôs até sanções civis, penais e administrativas na hipótese de descumprimento.

Entretanto, como já dito, o guardião da Constituição não pode ficar à mercê de uma regulamentação que nunca foi feita, pois alguns casos concretos exigem uma resposta rápida do STF. Na realidade, essa questão de legislar ou não, é uma ponderação de princípios e valores: o ser humano e sua dignidade versus o Poder Judiciário legislando para preencher lacuna normativa.

A par de todas essas argumentações, "quem tem poderes, hoje no Brasil, para declarar a inconstitucionalidade do ato normativo consubstanciado na Súmula Vinculante n. 11?” (SILVA, 2008). Pode-se inferir que o STF tem poderes até mais extensos do que o próprio Poder Legislativo. E o artigo 557 do CPC vem a corroborar com tal dedução: "O relator negará seguimento a recurso manifestamente inadmissível, improcedente, prejudicado ou em confronto com súmula ou com jurisprudência dominante do respectivo tribunal, do Supremo Tribunal Federal, ou de Tribunal Superior.”, o que deixa clara a função normativa da Corte. 


\section{UM ADENDO ESPECIAL QUANTO AOS PREJULGADOS E AO PODER NORMATIVO DAS JUSTIÇAS DO TRABALHO E ELEITORAL}

Como o prejulgado é uma ferramenta jurídica que já foi retirada tanto da Consolidação das Leis do Trabalho (CLT) quando do Código Eleitoral, iniciarse-á definindo o que é um prejulgado e qual é a sua principal finalidade:

Decisão preliminar tomada pelas câmaras de um tribunal para o estudo e boa interpretação ou solução normativa sobre determinado ponto de direito, para que possam dar uma interpretação uniforme (...). Após o acordo interpretativo sobre o ponto normativo visando à uniformidade da jurisprudência, será este, submetido a um consenso definitivo pelo órgão competente. (DICIONÁRIO Jurídico, 2012). (Grifo nosso).

\subsection{Prejulgados e Sentenças trabalhistas}

O artigo $902^{3}$ da CLT, com redação dada pelo Decreto-Lei 8.737/46, trazia em seu corpo a figura do prejulgado a qual poderia ser utilizada pelo Tribunal Superior do Trabalho (TST), além de possuir força vinculante para com os outros órgãos da justiça trabalhista. $\mathrm{O}$ artigo é bem claro ao permitir a pronúncia do tribunal tanto em relação a um caso concreto quanto a um caso em tese - ou seja, quando não há um caso em julgamento. No entanto, a polêmica gerada foi grande ao ponto de após 34 (trinta e quatro) anos de existência do prejulgado trabalhista, o STF o declarar inconstitucional por acórdão em 1977.

Dentre as diversas críticas estava a que uma lei ordinária não teria competência para permitir a um Tribunal produzir normas com efeito vinculante, obrigando os demais órgãos de instâncias inferiores e, também, de forma indireta, a sociedade. Assim, tal competência significava legislar, o que era inadmissível.

Apesar do fim dos prejulgados trabalhistas, a CLT ainda estipula um tipo de decisão, a chamada sentença normativa, quem tem efeitos vinculantes, como se pode ver em seus artigos $868^{4}$ a 871 . De forma sucinta, o principal efeito

\footnotetext{
3 Art. 902. É facultado ao Conselho Nacional do Trabalho estabelecer prejulgados, na forma que prescrever o seu regimento interno.

${ }^{4}$ Assim dizem os caput dos artigos 868 e 869:

Art. 868 - Em caso de dissídio coletivo que tenha por motivo novas condições de trabalho e no qual figure como parte apenas uma fração de empregados de uma empresa, poderá o Tribunal competente, na própria decisão, estender tais condições de trabalho, se julgar justo e conveniente, aos demais empregados da empresa que forem da mesma profissão dos dissidentes.

Art. 869 - A decisão sobre novas condições de trabalho poderá também ser estendida a todos os empregados da mesma categoria profissional compreendida na jurisdição do Tribunal
} 
gerado neste tipo de sentença é o de ser estender a empregados da mesma profissão da empresa ou até a todos os empregados da mesma categoria profissional o resultado de um dissídio coletivo com novas condições de trabalho. Claramente, os efeitos vão bem além das partes processuais.

Muitas discussões já existiram acerca de (in)constitucionalidade da sentença normativa, mas hoje em dia, tal polêmica cessou com os artigos $114 \mathrm{e}$ o artigo $5^{\circ}$, incisos XXI, da Constituição Federal, uma vez que a Carta Magna acolheu este tipo de sentença.

Deve-se frisar que o efeito trazido não é o erga omnes, mas ultrapartes, como defende Souza (2006), já que a eficácia é realmente além das partes, no entanto é restringida ao grupo ou categoria a que diz respeito o direito litigado. Já para os demais órgãos da Justiça trabalhista o efeito é vinculante conforme o artigo 872 da CLT:

Art. 872 - Celebrado o acordo, ou transitada em julgado a decisão, seguir-seá o seu cumprimento, sob as penas estabelecidas neste Título.

Parágrafo único - Quando os empregadores deixarem de satisfazer o pagamento de salários, na conformidade da decisão proferida, poderão os empregados ou seus sindicatos, independentes de outorga de poderes de seus associados, juntando certidão de tal decisão, apresentar reclamação à Junta ou Juízo competente, observado o processo previsto no Capítulo II deste Título, sendo vedado, porém, questionar sobre a matéria de fato e de direito já apreciada na decisão.

\subsection{Prejulgados e Resoluções eleitorais}

Semelhantemente, a Justiça Eleitoral também se utilizou dos prejulgados: "Art. 263. No julgamento de um mesmo pleito eleitoral, as decisões anteriores sobre questões de direito constituem prejulgados para os demais casos, salvo se contra a tese votarem dois terços dos membros do Tribunal." (Código Eleitoral, Lei 4.737/65). Dessa forma, os prejulgados eram precedentes para os demais tribunais ao julgarem casos parecidos de uma mesma eleição.

Ao se fazer um paralelo com o prejulgado trabalhista, nota-se duas diferenças: a primeira, diz respeito a um limite temporal, uma vez que o prejulgado eleitoral só podia ser invocado em relação a um mesmo pleito, assim, era como se o prejulgado perdesse a sua eficácia após o período das eleições no qual fora emitido; a segunda se refere a um limite da sua força vinculante, pois segundo a lei, o prejulgado se restringe apenas ao tribunal que o produziu. No entanto, o 
artigo 263 foi considerado pelo STF, em 1993, como inconstitucional, deixando assim, de existir.

Hodiernamente, tanto o Tribunal Superior Eleitoral (TSE) quanto os Tribunais Regionais Eleitorais (TRE) podem editar resoluções sobre qualquer tema eleitoral. Essa prática é claramente um poder normativo que foi permitido ao judiciário, são atos normativos, mesmo que, geralmente, provocados. Esses referidos tribunais - não os juízes eleitorais - têm o poder de emitir resoluções com o intuito de responder às consultas que são dúvidas em tese, em caso abstrato, "nunca em caso concreto" (SOUZA, 2006, p. 237). Da mesa forma também são respondidas: em tese.

Sobre o seu efeito vinculante existem controvérsias. Alguns doutrinadores acreditam que há sim, efeito vinculante tanto para o próprio tribunal que o editou quanto para os outros tribunais ou juízes eleitorais que sejam instância inferior ao emissor da resolução. Tal pensamento é justificado com o intuito de garantir a segurança jurídica, a previsibilidade do que é o direito e a celeridade exigida principalmente em períodos de eleição, já que as decisões correlatas devem ser uniformes, não pode um dia decidir de uma forma e no outro dia de jeito distinto.

Os que pensam contrariamente contestam a falta do perfeito contraditório e de um caso concreto, declarando ainda que seria inconstitucional permitir que uma norma infraconstitucional obrigue um juiz a decidir de modo tal que a peculiaridade do caso concreto não fosse analisada. No entanto, se deve observar dois detalhes. Primeiro, assim como o STF não pode decidir de forma contrária a sua súmula, o TSE deve seguir as suas resoluções, para isso, é necessária a natureza normativa. Segundo, o processo eleitoral possui características ímpares, uma vez que mais se assemelha à administração judicial do que à atividade jurisdicional em si. Portanto, defende-se aqui a força normativa das resoluções, por se entender ser demais necessária à garantia da democracia.

\section{DOS LIMITES DOS JUÍZES AO EXERCEREM FUNÇÃO ATÍPICA DE LEGISLAR}

E, por fim, deve-se questionar: quais são os limites da ação dos juízes como legisladores positivos? Zeni (2007) acredita que tal limite esteja dentro da "reserva da consistência" e da "reserva do possível".

O primeiro é a necessidade de o juiz fundamentar sua decisão judicial, a qual impõe a este que explique as razões de sua decisão: qual o caminho 
percorrido para se chegar à sentença, o que muitas vezes, devido à fuga de assuntos ao campo jurídico, é veementemente necessário a figura do amicus curiae. Assim, deve o judiciário comprovar que o ato judicial procede de adequada interpretação constitucional.

O segundo é o binômio do princípio da razoabilidade da pretensão da ação e a disponibilidade financeira do Estado. Em outras palavras: a realização de tais direitos pleiteados é razoável? Se positivo, é viável financeiramente ao Estado?

\section{CONSIDERAÇÕES FINAIS}

Procurou-se diversas opiniões com o intuito de polemizar e contribuir para a efetividade das normas, garantindo um processo cada vez mais rápido, eficaz e bem analisado, além de uniformidade em casos análogos. Reconhecendo, ainda, poderes limitados para o juiz poder agir de forma criativa, criar novo direito quando for preciso e, finalmente, responder à população como lhe é garantido.

E, a partir de todos os argumentos apresentados, pode-se dizer que, hodiernamente, no Brasil, o Poder Judiciário legisla, atipicamente, e ainda de forma tímida. No entanto, o Judiciário tem agido de forma satisfatória, protegendo, na medida do possível, os direitos das pessoas assegurados constitucional e internacionalmente.

Ao mesmo tempo, não se pode esquecer o legislativo e sua típica função, exigindo-se a prática da boa política e da celeridade das respostas à sociedade brasileira. Afinal, embora o Judiciário precise intervir em alguns casos, legislando positivamente, o legislativo não pode se acomodar. Enquanto o legislador está em silêncio, o Judiciário tem um dever a cumprir, sem abusos, sob novos limites, sob novos parâmetros constitucionais.

\section{REFERÊNCIAS}

AGÊNCIA BRASIL. Comissária da ONU critica demora do Congresso em aprovar projetos na área de direitos humanos. Disponível em: $<\mathrm{http}$ / /migre.me/dDXsM>. Acesso em: 3 out. 2012.

ALEXY, Robert. Teoria dos direitos fundamentais. 2. ed. São Paulo: Malheiros, 2011. 
BEMFICA, Francisco Vani. O juiz. O promotor. O advogado: seus poderes e deveres. 4. ed. Rio de Janeiro: Forense, 1995.

BINENBOJM, Gustavo. A Nova Jurisdição Constitucional Brasileira: legitimidade democrática e instrumentos de realização. 2. ed. Rio de Janeiro: Renovar, 2004.

CAPPELLETTI, Mauro. Juízes Legisladores? Tradução de Carlos Alberto Álvaro de Oliveira. Porto Alegre: Sérgio Antonio Fabris Editor, 1999.

CUNHA, Gross Luciana. et al. Relatório do Índice de Confiança na Justiça no Brasil (ICJ Brasil) - $1^{\circ}$ trimestre 2012. Disponível em: $<$ http:// bibliotecadigital.fgv.br/dspace/bitstream/handle/10438/9799/ Relat\%C3\%B3rio\%20ICJBrasil\%201\%C2\%BA\%20Trimestre\%20\%202012.pdf? sequence=1>. Acesso em: 3 out. 2012.

DICIONÁRIO Jurídico. Disponível em: $<$ http://www.sitesa.com.br/juridico/ dicionarios/ dicionario.html\#p>. Acesso em: 6 out. 2012.

DISTRITO FEDERAL. ADI 896/DF. Ação Direta de Inconstitucionalidade. 1993. Disponível em:<http://migre.me/ aDzNh>. Acesso em: 9 set. 2012.

LABOISSIÈRE, Paula. Comissária da ONU critica demora do Congresso em aprovar projetos na área de direitos humanos. Agência Brasil, 12 nov. 2009.

MENDES, Gilmar Ferreira. Jurisdição Constitucional: o controle abstrato de normas no Brasil e na Alemanha. 2. ed. São Paulo: Saraiva, 1998.

NUNES, Lucas. Súmula 25 / MS 8693. ADI n 1949-RS. 2009. Disponível em: <http://migre.me/aDzHd >. Acesso em: 9 set. 2012.

PINHEIRO, Victor Marcel. O STF como legislador negativo. Sociedade Brasileira de Direito Público. 2006. Disponível em:<http://www.sbdp.org.br/ arquivos/monografia/90_Victor\%20Marcel\%20Pinheiro.pdf>. Acesso em: 9 set. 2012. 
RIO GRANDE DO SUL. Supremo Tribunal Federal. ADI 3.459. 2005. Disponível em: < http://migre.me/aDA3O > . Acesso em 09 de set. de 2012.

RODRIGUES, Ticiano Marcel de Andrade. A atuação do legislador. DireitoNet. 30 abr. 2010. Disponível em:<http://www.direitonet.com.br/ artigos/exibir/5709/A-atuacao-do-legislador>. Acesso em: 3 out. 2012.

SILVA, Ivan Luís Marques da. Súmulas vinculantes: interpretar ou legislar? Eis a questão! LFG. 24 de dezembro de 2008. Disponível em: $<$ http:// www.lfg.com.br/public html/ article.php?story $=20081211101912565 \&$ mode $=$ print $>$. Acesso em: 12 jul. 2012.

SOUZA, Marcelo Alves Dias de. Do precedente judicial à súmula vinculante. Curitiba: Juruá, 2006.

TRANSPARÊNCIA BRASIL. Projeto Meritíssimos: desempenho dos ministros do STF. Disponível em: $<$ http://www.meritissimos.org.br/stf/ index.php>. Acesso em: 3 out. 2012.

ZENI, Carine. O Poder Judiciário como legislador positivo na efetivação dos direitos fundamentais sociais. Revista Grupo Integrado. Rev. Disc. Jur. Campo Mourão, v. 3, n. 2, p. 129-148, jul./dez. 2007. Disponível em: $<$ http:// revista.grupointegrado.br/revista/ index.php/discursojuridico/article/viewFile/ 217/103>. Acesso em 09 de set. de 2012.

Artigo recebido em: 30/10/2013 Aprovado para a publicação em: 03/12/2013

Como citar: DIAS, José Armando Ponte Dias Jr. DUARTE, Dayane Karla Barros De Farias. O poder judiciário como legislador positivo atípico. Revista do Direito Público. Londrina, v.8, n.3, p.131-166, set./dez. 2013. DOI: 10.5433/1980-511X.2013v8n3p131. 